\title{
Platelet distribution width as a prognostic factor in patients with COPD - pilot study
}

\author{
This article was published in the following Dove Press journal: \\ International Journal of COPD \\ I August 2017 \\ Number of times this article has been viewed
}

\author{
Adam J Białas ${ }^{1,2, *}$ \\ Claudio Pedone 3 ,* \\ Wojciech J Piotrowski, \\ Raffaele Antonelli Incalzi ${ }^{3}$ \\ 'Department of Pneumology and \\ Allergy, Medical University of Lodz, \\ Łódź, Poland; ${ }^{2}$ Healthy Aging Research \\ Centre (HARC), Medical University \\ of Lodz, Łódź, Poland; 'Department \\ of Geriatrics, Campus Bio-Medico \\ University of Rome, Rome, Italy \\ *These authors contributed equally \\ to this work
}

Background: Platelets may actively participate in inflammation in COPD. Platelet distribution width (PDW), a measure of platelets' volume heterogeneity, may increase in platelets' activation. We hypothesized that PDW may be a marker of hypercoagulation, which plays a significant role in conditions associated with worse survival of patients with COPD, eg, acute myocardial infarction and other forms of ischemic heart disease.

Methods: Retrospective analysis of 79 patients. Variables were compared after grouping patients according to the upper normal limit of PDW, using Welch's $t$-tests or Mann-Whitney $U$, and chi-square tests. Survival in the two groups was compared using the Kaplan-Meier method and Cox proportional hazards regression.

Results: Ten patients presented values of PDW above $16 \mathrm{fL}$, which was the upper limit of normality for our laboratory. Compared to patients with normal PDW, they had lower forced expiratory flow between $25 \%$ and $75 \%$ of vital capacity (FEF $25-75)-35 \%$ of reference value vs $57 \%(P=0.003)$ and peak expiratory flow $-39 \%$ vs $54 \%(P<0.001)$. The median survival of patients with elevated PDW was 743 days compared to those with normal PDW (1,305 days) $(P=0.025)$. The adjusted HR was 4.59 (95\% CI: 1.1, 19.19; $P=0.04)$.

Conclusion: Our analysis indicates that elevated PDW is associated with reduced survival of patients with COPD. If our data are to be confirmed, PDW may be used as an inexpensive and repeatable prognostic tool in COPD.

Keywords: COPD, PDW, platelets, inflammation, survival

\section{Background}

Increasing evidence suggests that the pathophysiology of COPD is characterized by the interaction between several factors, including local and systemic inflammation. ${ }^{1,2}$ IL-6 plays a central role in the inflammatory process underlying COPD, with increased concentrations reported in plasma, sputum, and exhaled breath of patients with COPD, especially during exacerbations. ${ }^{3-7}$ IL-6 stimulates the synthesis of acute phase proteins, but also affects platelet count by stimulating the differentiation of megakaryocytes into platelets and possibly by stimulating thrombopoietin production. ${ }^{8-12}$

It has been shown that platelets actively participate in inflammation in several conditions. ${ }^{13}$ Upon activation, platelets release chemokines from their $\alpha$-granules such as MIF, CXCL4, CXCL7 or CXCL5 which play a role in inflammatory processes. ${ }^{14}$ CXCL5 is a chemokine of potential importance in regulation of lung inflammation, by modulating neutrophil transepithelial and transendothelial migration and accumulation in the airspace. ${ }^{15}$ Furthermore, platelets regulate MMPs' activity which significantly contributes to inflammation. Platelets regulate MMPs both directly by secretion of the proteases and their inhibitors, and indirectly by influencing the behavior of other cells such as neutrophils and monocytes. ${ }^{16}$ Platelet-derived CD40L, which is shed from the
Correspondence: Adam J Białas Department of Pneumology and Allergy, Medical University of Lodz, 22 Kopcinski avenue 90-153 Lodz, Poland $\mathrm{Tel}+48426776699$

Fax +48426782129

Email adam.bialas@umed.lodz.pl (c) (i) (5) 2017 Białas et al. This work is published and licensed by Dove Medical Press Limited. The full terms of this license are available at https://www.dovepress.com/terms.php (c) hereby accept the Terms. Non-commercial uses of the work are permitted without any further permission from Dove Medical Press Limited, provided the work is properly attributed. For permission for commercial use of this work, please see paragraphs 4.2 and 5 of our Terms (https://www.dovepress.com/terms.php). 
platelet surfaces by MMPs, induces MT-1-MMP, MMP-1, MMP-2, and MMP-9 on endothelial cells. ${ }^{17,18}$ There is evidence proving the role of these MMPs in the pathophysiology of COPD. ${ }^{19-23}$

The routinely available indices which describe platelets' morphology and function are the platelet count (PLT), the platelet-to-lymphocyte ratio (PLR), the mean platelet volume (MPV), and the platelet distribution width (PDW). Thrombocytopenia was associated with poor outcomes in acute exacerbations of COPD. ${ }^{24}$ On the other hand, thrombocytosis may be associated with increased short- and long-term mortality after exacerbations. ${ }^{25}$ PLR describes the correlation between changes in levels of platelets and lymphocytes. PLR has been reported to play a significant role in cardiovascular diseases, ${ }^{26,27}$ diabetic ketoacidosis, ${ }^{28}$ and numerous neoplasms. ${ }^{8,12,29-40}$ MPV reflects changes in either the level of platelet stimulation or the rate of platelet production. ${ }^{41}$ It has been assessed as an inflammatory marker in several diseases. ${ }^{42-44}$ COPD patients, during acute exacerbation and in stable phase, have lower MPV compared with healthy controls, and the MPV increases once patients have recovered from exacerbation. ${ }^{45} \mathrm{PDW}$ is an index of platelets' volume heterogeneity ${ }^{46}$ and may increase in platelets' activation. ${ }^{47}$ The role of PDW has been assessed in several conditions, such as acute gangrenous appendicitis, carotid artery stenosis, coronary artery disease, angina pectoris, idiopathic pulmonary hypertension, ovarian torsion, and preeclampsia. ${ }^{48-56}$ PDW can serve as useful prognostic factor for long-term mortality in patients with acute myocardial infarction and was found to be an independent risk factors for cardiovascular mortality. ${ }^{57}$ Because hypercoagulation may play a significant role in conditions associated with worse survival of patients with COPD,${ }^{58,59}$ we hypothesized that PDW may be associated with survival in these patients. The objective of this study was to evaluate the mortality rate of patients with COPD with and without an abnormal PDW.

\section{Methods}

From the electronic archive of the Campus Bio-Medico Hospital in Rome, Italy, between March 2006 and December 2014, we identified 288 patients with post-bronchodilator forced expiratory volume in 1 second to forced vital capacity ratio $\left(\mathrm{FEV}_{1} / \mathrm{FVC}\right)<0.7$ and for whom information on vital status could be obtained from the regional death registry. Subsequently, we selected patients with a blood cell count performed within 2 weeks of the index spirometry (N: 92).
We excluded patients with conditions that, based on the available evidence, may affect PDW: acute exacerbation of COPD, any active acute inflammation, connective tissue disorder, diabetic ketoacidosis, recent history of myocardial infarction, end-stage renal disease, history of any active malignancy, and hematological system diseases, or blood transfusion in the last 2 months.

Demographic data, medical history, and routine laboratory measurements, including white blood count, neutrophils, lymphocytes, PLT, MPV, and PDW, were collected from the digital database of medical records of Campus Bio-Medico di Roma.

Pulmonary function tests (PFTs) including vital capacity (VC), FVC, $\mathrm{FEV}_{1}, \mathrm{FEV}_{1} / \mathrm{FVC}$ ratio, forced expiratory flow between $25 \%$ and $75 \%$ of VC (FEF 25-75), peak expiratory flow (PEF), total lung capacity (TLC), and residual volume, were collected from the digital database of medical records of Campus Bio-Medico di Roma. PFTs were performed with the water-bell volume spirometry device between March 2006 and December 2012 by the same technician. All lung function parameters were measured according to the American Thoracic Society/European Respiratory Society guidelines. ${ }^{60-63}$

Continuous data are presented as the mean with $95 \%$ CI, except survival that was presented as median. Variables were compared after grouping patients according to the laboratory upper limit of PDW, using $t$-test for normally distributed continuous data, and Mann-Whitney $U$ test for not normally distributed continuous data. Categorical variables were compared using chi-square test with Yates' continuity correction.

Survival analysis was performed after grouping patients according to the laboratory normal limit for PDW values. Kaplan-Meier analysis and log-rank test were used to compare survival curves. Multivariable analyses were performed using Cox proportional hazards regression to adjust for age, comorbidities, and $\mathrm{FEV}_{1}$.

Data were analyzed using R software for MacOS (R Core Team [2016]. R: A language and environment for statistical computing. R Foundation for Statistical Computing, Vienna, Austria).

The protocol of the study was approved by the Ethics Committee of the Campus Bio-Medico University.

\section{Results}

Seventy-nine patients met the inclusion criteria. The flow chart of sample selection is reported in Figure 1. Most patients 


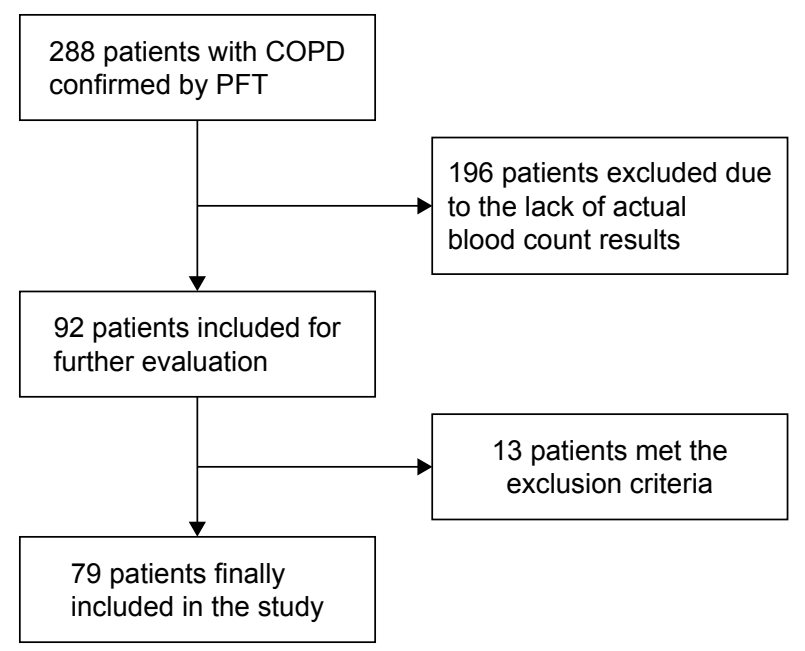

Figure I Flow chart of patient selection for inclusion in the study. Abbreviation: PFT, pulmonary function test.

were GOLD stage II (49.4\%), ex-smokers (62.5\%), and had comorbidities $(90 \%)$. Mean age of the study population was 73.6 (95\% CI: 72.32, 74.95). The overall male-to-female ratio was 1.93:1. The means of baseline values of the study population are presented in Table 1.

Ten patients presented values of PDW above $16 \mathrm{fL}$, which was the upper limit of normality for our laboratory. There were no differences in age and gender distribution between the groups. Participants with higher PDW showed significantly lower FEF 25-75 and PEF values compared to those with normal PDW - both in absolute values, and expressed as percent of reference value (Table 2).

Patients with high PDW had worse survival compared to patients with normal PDW, with a median survival time of 743 days compared to 1,305 days of patients with normal PDW (Figure 2). Log rank test showed significant differences between groups (chi-square $=4.9 ; P=0.025$ ). Abnormal PDW values were associated with an RR of death of $3.18(95 \%$ CI $0.6,7.79 ; P=0.07)$. The HR for unadjusted Cox regression was 4.34 (95\% CI: 1.072, 17.6; $P=0.04)$ and HR after adjustment for gender, age, comorbidities, and $\mathrm{FEV}_{1} \%$ was 4.59 (95\% CI: 1.1, 19.19; $P=0.04)$.

\section{Discussion}

In our study, we found that elevated PDW was associated with increased risk for mortality in COPD patients. This result was confirmed after adjustment for age, comorbidities, and $\mathrm{FEV}_{1} \%$, suggesting that in our sample PDW was an independent risk factor for mortality.

Activation of platelets causes morphological changes, including pseudopodia formation. Pseudopodium formation
Table I Baseline values of the study population

\begin{tabular}{|c|c|c|}
\hline Parameter & Mean & $95 \% \mathrm{Cl}$ \\
\hline WBC $\left(\times 10^{\wedge} 3 / \mu \mathrm{L}\right)$ & 7.06 & $6.63,7.49$ \\
\hline Neutrophils $\left(\times 10^{\wedge} 3 / \mu \mathrm{L}\right)$ & 4.26 & $3.89,4.63$ \\
\hline Lymphocytes $\left(\times 10^{\wedge} 3 / \mu \mathrm{L}\right)$ & 2.08 & I.87, 2.3 \\
\hline Platelet count $\left(\times 10^{\wedge} 3 / \mu \mathrm{L}\right)$ & 224.1 & $202.58,245.55$ \\
\hline $\mathrm{MPV}(\mathrm{fL})$ & 10.91 & $10.69,11.13$ \\
\hline PDW (fL) & 13.36 & $12.9,13.8$ \\
\hline PLR & 123.13 & $108.82,137.44$ \\
\hline \multicolumn{3}{|l|}{ Pre-bronchodilator } \\
\hline VC (L) & 2.49 & $2.3,2.67$ \\
\hline FVC (L) & 2.47 & $2.28,2.65$ \\
\hline FVC (\%) & 76.09 & $72,80.17$ \\
\hline $\mathrm{FEV}_{1}(\mathrm{~L})$ & 1.47 & $1.33,1.6$ \\
\hline $\mathrm{FEV}_{1}(\%)$ & 59.29 & $54.92,63.67$ \\
\hline $\mathrm{FEV}_{1} / \mathrm{FVC}$ & 0.59 & $0.57,0.61$ \\
\hline FEF $25-75$ (L/s) & 0.7 & $0.62,0.78$ \\
\hline FEF 25-75 (\%) & 36.1 & $32.35,39.86$ \\
\hline PEF (L) & 3.68 & $3.32,4.04$ \\
\hline PEF (\%) & 45.57 & $41.62,49.52$ \\
\hline \multicolumn{3}{|l|}{ Post-bronchodilator } \\
\hline VC (L) & 2.7 & $2.52,2.89$ \\
\hline FVC (L) & 2.68 & $2.5,2.87$ \\
\hline FVC (\%) & 82.78 & $78.84,86.73$ \\
\hline $\mathrm{FEV}_{1}(\mathrm{~L})$ & 1.62 & $1.48,1.75$ \\
\hline $\mathrm{FEV}_{1}(\%)$ & 65.29 & $60.9,69.67$ \\
\hline $\mathrm{FEV}_{1} / \mathrm{FVC}$ & 0.6 & $0.57,0.62$ \\
\hline FEF 25-75 (L/s) & 0.996 & $0.89,1.1$ \\
\hline FEF 25-75 (\%) & 54.5 & $47.37,61.62$ \\
\hline $\operatorname{PEF}(\mathrm{L})$ & 4.01 & $3.66,4.36$ \\
\hline PEF (\%) & 51.91 & $46.66,57.16$ \\
\hline $\mathrm{TLC}(\mathrm{L})$ & 4.89 & $4.63,5.15$ \\
\hline \multirow[t]{2}{*}{$\mathrm{RV}(\mathrm{L})$} & 2.42 & $2.27,2.57$ \\
\hline & Number of patients & Percent (\%) \\
\hline Comorbidities & 71 & 89.9 \\
\hline Respiratory & 14 & 17.7 \\
\hline Cardiovascular & 63 & 79.7 \\
\hline Mental & 9 & 11.4 \\
\hline Endocrine system & 11 & 13.9 \\
\hline Central nervous system & 10 & 12.7 \\
\hline Diabetes mellitus type 2 & 18 & 22.8 \\
\hline Other & 47 & 59.5 \\
\hline \multicolumn{3}{|l|}{ Smoking history } \\
\hline Smoker & $18 / 72^{\mathrm{a}}$ & 25 \\
\hline Non-smoker & $9 / 72^{\mathrm{a}}$ & 12.5 \\
\hline Ex-smoker & $45 / 72^{\mathrm{a}}$ & 62.5 \\
\hline \multicolumn{3}{|l|}{ GOLD } \\
\hline I stage & 20 & 25.3 \\
\hline II stage & 39 & 49.4 \\
\hline III stage & 17 & 21.5 \\
\hline IV stage & 3 & 3.8 \\
\hline
\end{tabular}

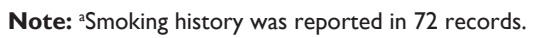

Abbreviations: FEF $25-75$, forced expiratory flow between $25 \%$ and $75 \%$ of vital capacity; FEV , forced expiratory volume in I second; FVC, forced vital capacity; GOLD, Global initiative for chronic Obstructive Lung Disease; MPV, mean platelet volume; PDW, platelet distribution width; PEF, peak expiratory flow; PLR, plateletto-lymphocyte ratio; RV, residual volume; TLC, total lung capacity; VC, vital capacity; WBC, white blood count. 
Table 2 Functional and demographic parameters of the study population according to upper limit of PDW values

\begin{tabular}{|c|c|c|c|c|c|}
\hline \multirow[t]{2}{*}{ Parameter } & \multirow{2}{*}{$\begin{array}{l}P D W \leq 16 \text { (fL) } \\
n=69 \\
\text { Mean }\end{array}$} & \multirow{2}{*}{$\begin{array}{l}\text { PDW }>16 \text { (fL) } \\
n=10 \\
\text { Mean }\end{array}$} & \multirow{2}{*}{$\begin{array}{l}\text { Mean } \\
\text { difference }\end{array}$} & \multicolumn{2}{|c|}{ Comparison result } \\
\hline & & & & $95 \% \mathrm{Cl}$ & $P$-value \\
\hline Age (years) & 73.57 & 74.1 & & & $0.64^{\mathrm{a}}$ \\
\hline WBC $\left(\times 10^{\wedge} 3 / \mu \mathrm{L}\right)$ & 7.05 & 7.15 & & & $0.89^{a}$ \\
\hline Neutrophils $\left(\times 10^{\wedge} 3 / \mu \mathrm{L}\right)$ & 4.28 & 4.14 & 0.15 & $-0.97,1.26$ & 0.8 \\
\hline Lymphocytes $\left(\times 10^{\wedge} 3 / \mu \mathrm{L}\right)$ & 2.05 & 2.26 & & & $0.63^{\mathrm{a}}$ \\
\hline Platelet count $\left(\times 10^{\wedge} 3 / \mu \mathrm{L}\right)$ & 229.94 & 183.5 & 46.44 & $-17.74,110.63$ & 0.15 \\
\hline $\mathrm{MPV}(\mathrm{fL})$ & 10.68 & 12.52 & -1.84 & $-2.36,-1.32$ & $<0.001$ \\
\hline PLR & 125.34 & 107.89 & & & $0.42^{\mathrm{a}}$ \\
\hline $\mathrm{VC}(\mathrm{L})^{\mathrm{b}}$ & 2.67 & 2.9 & -0.23 & $-0.79,0.32$ & 0.4 \\
\hline $\mathrm{FVC}(\mathrm{L})^{\mathrm{b}}$ & 2.65 & 2.89 & -0.24 & $-0.8,0.32$ & 0.4 \\
\hline FVC $(\%)^{b}$ & 82.64 & 83.8 & -1.17 & $-13.1,10.76$ & 0.85 \\
\hline $\mathrm{FEV}_{1}(\mathrm{~L})^{\mathrm{b}}$ & 1.59 & 1.82 & -0.23 & $-0.65,0.18$ & 0.26 \\
\hline $\mathrm{FEV}_{1}(\%)^{\mathrm{b}}$ & 64.69 & 69.37 & -4.68 & $-17.9,8.54$ & 0.48 \\
\hline $\mathrm{FEV}_{1} / \mathrm{FVC}^{\mathrm{b}}$ & 0.6 & 0.57 & & & $0.2^{\mathrm{a}}$ \\
\hline FEF $25-75(\mathrm{~L} / \mathrm{s})^{\mathrm{b}}$ & 1.04 & 0.69 & 0.35 & $0.11,0.59$ & 0.007 \\
\hline FEF $25-75$ (\%) $^{\mathrm{b}}$ & 57.27 & 35.4 & 21.87 & $8.16,35.58$ & 0.003 \\
\hline $\operatorname{PEF}(\mathrm{L} / \mathrm{s})^{\mathrm{b}}$ & 4.13 & 3.17 & 0.96 & $0.32, \mathrm{I} .6 \mathrm{I}$ & 0.005 \\
\hline PEF $(\%)^{b}$ & 53.85 & 38.54 & $|5.3|$ & $6.82,23.78$ & $<0.001$ \\
\hline TLC (L) & 4.9 & 4.79 & 0.11 & $-0.64,0.88$ & 0.76 \\
\hline \multirow[t]{2}{*}{$\mathrm{RV}(\mathrm{L})$} & 2.39 & 2.65 & & & $0.25^{\mathrm{a}}$ \\
\hline & $\begin{array}{l}\text { Number of } \\
\text { patients and } \\
\text { percent } \\
n=69\end{array}$ & $\begin{array}{l}\text { Number of } \\
\text { patients and } \\
\text { percent } \\
n=10\end{array}$ & & & $P$-value \\
\hline Gender & & & & & 0.51 \\
\hline Male & 44 (63.77\%) & $8(80 \%)$ & & & \\
\hline Female & $25(36.23 \%)$ & $2(20 \%)$ & & & \\
\hline Smoking history & 63 & 9 & & & 0.91 \\
\hline Smoker & $15(23.81 \%)$ & $3(33.3 \%)$ & & & \\
\hline Non-smoker & $8(12.7 \%)$ & I (II.I\%) & & & \\
\hline Ex-smoker & $40(63.49 \%)$ & $5(55.6 \%)$ & & & \\
\hline GOLD stages of airway & & & & & 0.90 \\
\hline \multicolumn{6}{|l|}{ obstruction } \\
\hline 1 & $16(23.19 \%)$ & $4(40 \%)$ & & & \\
\hline II & 35 (50.72\%) & $4(40 \%)$ & & & \\
\hline III & $15(21.74 \%)$ & $2(20 \%)$ & & & \\
\hline IV & $3(4.35 \%)$ & 0 & & & \\
\hline \multicolumn{6}{|l|}{ Comorbidities } \\
\hline Respiratory & $13(18.84 \%)$ & I (I0\%) & & & 0.81 \\
\hline Cardiovascular & 55 (79.7I\%) & $8(80 \%)$ & & & 0.98 \\
\hline Mental & $8(11.59 \%)$ & $\mathrm{I}(10 \%)$ & & & 0.88 \\
\hline Endocrine system & $9(13.04 \%)$ & $2(20 \%)$ & & & 0.92 \\
\hline $\begin{array}{l}\text { Central nervous } \\
\text { system }\end{array}$ & $10(14.49 \%)$ & 0 & & & 0.44 \\
\hline $\begin{array}{l}\text { Diabetes mellitus } \\
\text { type } 2\end{array}$ & $16(23.19 \%)$ & $2(20 \%)$ & & & 0.82 \\
\hline Other & 40 (57.97\%) & 7 (70\%) & & & 0.7 \\
\hline
\end{tabular}

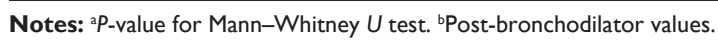

Abbreviations: FEF $25-75$, forced expiratory flow between $25 \%$ and $75 \%$ of vital capacity; FEV , forced expiratory volume in I second; FVC, forced vital capacity; GOLD, Global initiative for chronic Obstructive Lung Disease; MPV, mean platelet volume; PDW, platelet distribution width; PEF, peak expiratory flow; PLR, platelet-to-lymphocyte ratio; RV, residual volume; TLC, total lung capacity; VC, vital capacity; WBC, white blood count.

enhances platelet-surface interactions (adhesion) and platelet-platelet interaction (cohesion) ${ }^{64}$ Progressively activated platelets with pseudopodia formation have heterogeneous size, and PDW may increase. ${ }^{47}$ The association of PDW with survival may be hypothetically linked with hypercoagulation, which plays a significant role in conditions associated with survival in COPD, eg, acute myocardial infarction and other forms of ischemic heart disease..$^{58,59}$ 


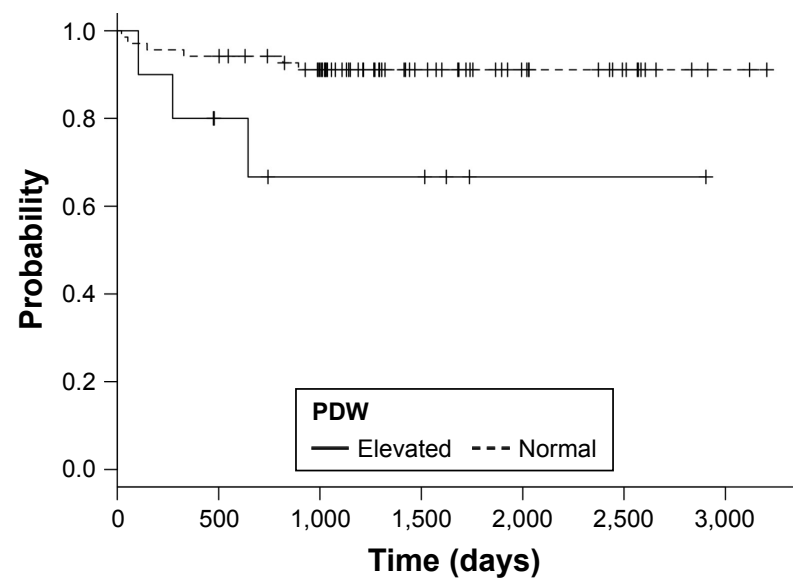

Figure 2 Kaplan-Meier curves for normal and elevated PDW values. Abbreviation: PDW, platelet distribution width.

According to Wang et al, elevated PDW is a risk factor for pulmonary embolism and may be observed in COPD patients with this condition. ${ }^{65}$

Our results are in line with other evidence which shows that PDW may be a marker of COPD exacerbations, ${ }^{66}$ while patients with stable COPD do not seem to have higher PDW compared to controls ${ }^{67}$ Furthermore, the use of antiplatelet drugs was associated with improved survival in oxygendependent COPD patients. ${ }^{68}$

While we excluded patients with diseases with an obvious impact on PDW or inflammation, in our sample, comorbidities were common, eg, prevalence of diabetes mellitus was $23 \%$. Makhlouf et al showed that COPD patients with diabetes mellitus had significantly higher PDW compared to healthy controls, but there was no difference in PDW between COPD patients with and without diabetes mellitus. ${ }^{69}$

We found significantly lower values of FEF $25-75$ and PEF among patients with elevated PDW. This is a novel finding in a population of patients with COPD. Indeed, FEF 25-75 reflects the expiratory flows in peripheral airways, whereas PEF is strictly dependent upon the strength of expiratory muscles. Thus, these findings, though preliminary in nature, suggest that higher PDW, as a marker of inflammatory and hypercoagulable status, is linked to lung metabolism/inflammation and sarcopenia. Unfortunately, we lacked additional information, such as breath pattern analysis and direct measurement of respiratory muscle strength, to test this hypothesis. However, we think that it is unlikely that PDW per se has any direct effect on pulmonary function. The associations that we have found are most likely due to platelet morphology acting as a marker for some other biological process, such as inflammation. Due to the retrospective character of our study, causal relationship cannot be verified, and our results must also be interpreted in light of the fact that both of these parameters have limited clinical value in COPD, while we found no difference in spirometric parameters known to have important prognostic significance $\left(\mathrm{FEV}_{1}, \mathrm{FVC}\right)$. Measurement of FEF 25-75 does not contribute to clinical decision making. ${ }^{70} \mathrm{PEF}$ is recorded in the first tenth of a second of forced expiration, while $\mathrm{FEV}_{1}$ continues to record forced expiration for a further $0.9 \mathrm{~s}$, therefore $\mathrm{FEV}_{1}$ records what happens to expired air after peak flow is reached. It is in this component of forced expiration that the changes characteristic of COPD are observed. ${ }^{71}$

There are some limitations of our study that need to be taken into account. Our sample size is relatively small and we could not fully investigate the relationship between PFT and PDW. Furthermore, our study is a retrospective analysis and we have to be aware of a risk of selection bias.

\section{Conclusion}

Our pilot analysis shows that PDW is associated with survival in patients with COPD. As it can be simply and rapidly measured from routine blood examination, should our results be confirmed in larger samples, it may prove to be a widely available, inexpensive, and repeatable prognostic marker. Furthermore, it might contribute to the characterization of the phenotypic variability of COPD.

\section{Author contributions}

AJB - study conception, design, and coordination, acquisition of data, analysis, and interpretation of data, statistical analysis, drafting of manuscript; CP - study conception, design, and coordination, acquisition of data, analysis and interpretation of data, statistical analysis, drafting of manuscript; WJP - contributed to the design of the study, analysis, and interpretation of data, critical revision; RAI - study design and coordination, analysis and interpretation of data, critical revision, drafting of manuscript. All authors edited and approved the final version of the manuscript.

\section{Disclosure}

The authors report no conflicts of interest in this work.

\section{References}

1. Barnes PJ. The cytokine network in chronic obstructive pulmonary disease. Am J Respir Cell Mol Biol. 2009;41(6):631-638.

2. Agusti AG. COPD, a multicomponent disease: implications for management. Respir Med. 2005;99(6):670-682.

3. Bhowmik A, Seemungal TA, Sapsford RJ, Wedzicha JA. Relation of sputum inflammatory markers to symptoms and lung function changes in COPD exacerbations. Thorax. 2000;55(2):114-120. 
4. Bucchioni E, Kharitonov SA, Allegra L, Barnes PJ. High levels of interleukin- 6 in the exhaled breath condensate of patients with COPD. Respir Med. 2003;97(12):1299-1302.

5. Gessner C, Scheibe R, Wötzel M, et al. Exhaled breath condensate cytokine patterns in chronic obstructive pulmonary disease. Respir Med. 2005;99(10):1229-1240.

6. Emami Ardestani M, Zaerin O. Role of serum interleukin 6, albumin and C-reactive protein in COPD Patients. Tanaffos. 2015;14(2):134-140.

7. Yasuda N, Gotoh K, Minatoguchi S, et al. An increase of soluble Fas, an inhibitor of apoptosis, associated with progression of COPD. Respir Med. 1998;92(8):993-999.

8. Templeton AJ, Ace O, McNamara MG, et al. Prognostic role of platelet to lymphocyte ratio in solid tumors: a systematic review and metaanalysis. Cancer Epidemiol Biomark Prev. 2014;23(7):1204-1212.

9. Ohsugi Y. Recent advances in immunopathophysiology of interleukin-6: an innovative therapeutic drug, tocilizumab (recombinant humanized anti-human interleukin-6 receptor antibody), unveils the mysterious etiology of immune-mediated inflammatory diseases. Biol Pharm Bull. 2007;30(11):2001-2006.

10. Imai T, Koike K, Kubo T, et al. Interleukin-6 supports human megakaryocytic proliferation and differentiation in vitro. Blood. 1991;78(8): 1969-1974.

11. Lippitz BE. Cytokine patterns in patients with cancer: a systematic review. Lancet Oncol. 2013;14(6):e218-e228.

12. Klinger MH, Jelkmann W. Role of blood platelets in infection and inflammation. J Interferon Cytokine Res. 2002;22(9):913-922.

13. Nording HM, Seizer P, Langer HF. Platelets in inflammation and atherogenesis. Front Immunol. 2015;6:98.

14. Karshovska E, Weber C, von Hundelshausen P. Platelet chemokines in health and disease. Thromb Haemost. 2013;110(5):894-902.

15. Mei J, Liu Y, Dai N, et al. CXCL5 regulates chemokine scavenging and pulmonary host defense to bacterial infection. Immunity. 2010;33(1): $106-117$.

16. Seizer P, May AE. Platelets and matrix metalloproteinases. Thromb Haemost. 2013;110(5):903-909.

17. Rahman M, Roller J, Zhang S, et al. Metalloproteinases regulate CD40L shedding from platelets and pulmonary recruitment of neutrophils in abdominal sepsis. Inflamm Res. 2012;61(6):571-579.

18. May AE, Kälsch T, Massberg S, Herouy Y, Schmidt R, Gawaz M. Engagement of glycoprotein IIb/IIIa (alpha(IIb)beta3) on platelets upregulates CD40L and triggers CD40L-dependent matrix degradation by endothelial cells. Circulation. 2002;106(16):2111-2117.

19. Skjøt-Arkil H, Clausen RE, Nguyen QH, et al. Measurement of MMP-9 and -12 degraded elastin (ELM) provides unique information on lung tissue degradation. BMC Pulm Med. 2012;12:34.

20. Ilumets $H$, Rytilä $P$, Demedts I, et al. Matrix metalloproteinases $-8,-9$ and -12 in smokers and patients with stage 0 COPD. Int $J$ Chron Obstruct Pulmon Dis. 2007;2(3):369-379.

21. Brajer B, Batura-Gabryel H, Nowicka A, Kuznar-Kaminska B, Szczepanik A. Concentration of matrix metalloproteinase-9 in serum of patients with chronic obstructive pulmonary disease and a degree of airway obstruction and disease progression. J Physiol Pharmacol. 2008;59 Suppl 6:145-152.

22. Kwiatkowska S, Noweta K, Zieba M, Nowak D, Bialasiewicz P. Enhanced exhalation of matrix metalloproteinase- 9 and tissue inhibitor of metalloproteinase- 1 in patients with COPD exacerbation: a prospective study. Respiration. 2012;84(3):231-241.

23. Navratilova Z, Zatloukal J, Kriegova E, Kolek V, Petrek M. Simultaneous up-regulation of matrix metalloproteinases 1, 2, 3, 7, 8, 9 and tissue inhibitors of metalloproteinases 1, 4 in serum of patients with chronic obstructive pulmonary disease. Respirology. 2012;17(6): 1006-1012.

24. Rahimi-Rad MH, Soltani S, Rabieepour M, Rahimirad S. Thrombocytopenia as a marker of outcome in patients with acute exacerbation of chronic obstructive pulmonary disease. Pneumonol Alergol Pol. 2015; 83(5):348-351.
25. Harrison MT, Short P, Williamson PA, Singanayagam A, Chalmers JD, Schembri S. Thrombocytosis is associated with increased short and long term mortality after exacerbation of chronic obstructive pulmonary disease: a role for antiplatelet therapy? Thorax. 2014;69(7): 609-615.

26. Azab B, Shah N, Akerman M, McGinn JT Jr. Value of platelet/lymphocyte ratio as a predictor of all-cause mortality after non-ST-elevation myocardial infarction. J Thromb Thrombolysis. 2012;34(3):326-334.

27. Sunbul M, Gerin F, Durmus E, et al. Neutrophil to lymphocyte and platelet to lymphocyte ratio in patients with dipper versus non-dipper hypertension. Clin Exp Hypertens. 2014;36(4):217-221.

28. Liu WY, Lin SG, Wang LR, et al. Platelet-to-lymphocyte ratio: a novel prognostic factor for prediction of 90-day outcomes in critically ill patients with diabetic ketoacidosis. Medicine (Baltimore). 2016;95(4): e2596.

29. Asher V, Lee J, Innamaa A, Bali A. Preoperative platelet lymphocyte ratio as an independent prognostic marker in ovarian cancer. Clin Transl Oncol. 2011;13(7):499-503.

30. Bhatti I, Peacock O, Lloyd G, Larvin M, Hall RI. Preoperative hematologic markers as independent predictors of prognosis in resected pancreatic ductal adenocarcinoma: neutrophil-lymphocyte versus platelet-lymphocyte ratio. Am J Surg. 2010;200(2):197-203.

31. Carruthers R, Tho LM, Brown J, Kakumanu S, McCartney E, McDonald AC. Systemic inflammatory response is a predictor of outcome in patients undergoing preoperative chemoradiation for locally advanced rectal cancer. Colorectal Dis. 2012;14(10):e701-e707.

32. Dutta S, Crumley AB, Fullarton GM, Horgan PG, McMillan DC. Comparison of the prognostic value of tumour and patient related factors in patients undergoing potentially curative resection of gastric cancer. Am J Surg. 2012;204(3):294-299.

33. Dutta S, Crumley AB, Fullarton GM, Horgan PG, McMillan DC. Comparison of the prognostic value of tumour- and patient-related factors in patients undergoing potentially curative resection of oesophageal cancer. World J Surg. 2011;35(8):1861-1866.

34. Fox P, Hudson M, Brown C, et al. Markers of systemic inflammation predict survival in patients with advanced renal cell cancer. Br JCancer. 2013; 109(1):147-153.

35. Raungkaewmanee S, Tangjitgamol S, Manusirivithaya S, Srijaipracharoen S, Thavaramara T. Platelet to lymphocyte ratio as a prognostic factor for epithelial ovarian cancer. J Gynecol Oncol. 2012; 23(4):265-273.

36. Smith RA, Bosonnet L, Raraty M, et al. Preoperative plateletlymphocyte ratio is an independent significant prognostic marker in resected pancreatic ductal adenocarcinoma. Am J Surg. 2009;197(4): 466-472.

37. Wang DS, Luo HY, Qiu MZ, et al. Comparison of the prognostic values of various inflammation based factors in patients with pancreatic cancer. Med Oncol. 2012;29(5):3092-3100.

38. Wang DS, Ren C, Qiu MZ, et al. Comparison of the prognostic value of various preoperative inflammation-based factors in patients with stage III gastric cancer. Tumour Biol. 2012;33(3):749-756.

39. Li X, Chen ZH, Xing YF, et al. Platelet-to-lymphocyte ratio acts as a prognostic factor for patients with advanced hepatocellular carcinoma. Tumour Biol. 2015;36(4):2263-2269.

40. Tian X, Zeng F, Wu D. Platelet-to-lymphocyte ratio: a prognostic factor for patients with advanced hepatocellular carcinoma? Tumour Biol. 2015; 36(7):4935-4936.

41. Bancroft AJ, Abel EW, Mclaren M, Belch JJ. Mean platelet volume is a useful parameter: a reproducible routine method using a modified Coulter thrombocytometer. Platelets. 2000;11(7):379-387.

42. Gasparyan AY, Ayvazyan L, Mikhailidis DP, Kitas GD. Mean platelet volume: a link between thrombosis and inflammation? Curr Pharm Des. 2011;17(1):47-58.

43. Kim DS, Lee J, Kim SH, Kim SM, Lee MG. Mean platelet volume is elevated in patients with psoriasis vulgaris. Yonsei Med J. 2015;56(3): $712-718$. 
44. Kisacik B, Tufan A, Kalyoncu U, et al. Mean platelet volume (MPV) as an inflammatory marker in ankylosing spondylitis and rheumatoid arthritis. Joint Bone Spine. 2008;75(3):291-294.

45. Wang RT, Li JY, Cao ZG, Li Y. Mean platelet volume is decreased during an acute exacerbation of chronic obstructive pulmonary disease. Respirology. 2013;18(8):1244-1248.

46. Bessman JD, Williams LJ, Gilmer PR Jr. Platelet size in health and hematologic disease. Am J Clin Pathol. 1982;78(2):150-153.

47. Bae MH, Lee JH, Yang DH, Park HS, Cho Y, Chae SC. White blood cell, hemoglobin and platelet distribution width as short-term prognostic markers in patients with acute myocardial infarction. J Korean Med Sci. 2014;29(4):519-526.

48. Fan Z, Pan J, Zhang Y, et al. Mean platelet volume and platelet distribution width as markers in the diagnosis of acute gangrenous appendicitis. Dis Markers. 2015;2015:542013.

49. Aydogan A, Akkucuk S, Arica S, et al. The analysis of mean platelet volume and platelet distribution width levels in appendicitis. Indian J Surg. 2015;77(Suppl 2):495-500.

50. Koklu E, Yuksel IO, Arslan S, et al. Predictors of symptom development in intermediate carotid artery stenosis: mean platelet volume and platelet distribution width. Angiology. 2016;67(7):622-629.

51. Yilmaz M, Cimilli G, Saritemur M, et al. Diagnostic accuracy of neutrophil/lymphocyte ratio, red cell distribution width and platelet distribution width in ovarian torsion. J Obstet Gynaecol. 2016;36(2):218-222.

52. Karateke A, Kurt RK, Baloğlu A. Relation of platelet distribution width (PDW) and platelet crit (PCT) to preeclampsia. Ginekol Pol. 2015; 86(5):372-375.

53. Zheng YG, Yang T, Xiong CM, et al. Platelet distribution width and mean platelet volume in idiopathic pulmonary arterial hypertension. Heart Lung Circ. 2015;24(6):566-572.

54. Ozyurtlu F, Yavuz V, Cetin N, Acet H, Ayhan E, Isik T. The association between coronary slow flow and platelet distribution width among patients with stable angina pectoris. Postępy Kardiol Interwencyjnej. 2014;10(3):161-165.

55. Adam G, Kocak E, Özkan A, et al. Evaluation of platelet distribution width and mean platelet volume in patients with carotid artery stenosis. Angiology. 2015;66(4):375-378.

56. Bekler A, Ozkan MT, Tenekecioglu E, et al. Increased platelet distribution width is associated with severity of coronary artery disease in patients with acute coronary syndrome. Angiology. 2015;66(7): 638-643.
57. Rechciński T, Jasińska A, Foryś J, et al. Prognostic value of platelet indices after acute myocardial infarction treated with percutaneous coronary intervention. Cardiol J. 2013;20(5):491-498.

58. Hansell AL, Walk JA, Soriano JB. What do chronic obstructive pulmonary disease patients die from? A multiple cause coding analysis. Eur Respir J. 2003;22(5):809-814.

59. Zielinski J, MacNee W, Wedzicha J, et al. Causes of death in patients with COPD and chronic respiratory failure. Monaldi Arch Chest Dis. 1997;52(1):43-47.

60. Miller MR, Hankinson J, Brusasco V, et al. Standardisation of spirometry. Eur Respir J. 2005;26(2):319-338.

61. Miller MR, Crapo R, Hankinson J, et al. General considerations for lung function testing. Eur Respir J. 2005;26(1):153-161.

62. Wanger J, Clausen JL, Coates A, et al. Standardisation of the measurement of lung volumes. Eur Respir J. 2005;26(3):511-522.

63. Macintyre N, Crapo RO, Viegi G, et al. Standardisation of the singlebreath determination of carbon monoxide uptake in the lung. Eur RespirJ. 2005;26(4):720-735.

64. Rodger L Bick, Genesio Murano. Physiology of hemostasis. In: Disorders of Thrombosis and Hemostasis: Clinical and Laboratory Practice. Lippincott Williams \& Wilkins; 2002:6.

65. Wang M, Zhang J, Ji Q, et al. Evaluation of platelet distribution width in chronic obstructive pulmonary disease patients with pulmonary embolism. Biomark Med. 2016;10:587-596.

66. Karadeniz G, Aktoğu S, Erer OF, et al. Predictive value of plateletto-lymphocyte ratio in exacerbation of chronic obstructive pulmonary disease. Biomark Med. 2016;10(7):701-710.

67. Steiropoulos P, Papanas N, Nena E, et al. Mean platelet volume and platelet distribution width in patients with chronic obstructive pulmonary disease: the role of comorbidities. Angiology. 2013;64(7):535-539.

68. Ekström MP, Hermansson AB, Ström KE. Effects of cardiovascular drugs on mortality in severe chronic obstructive pulmonary disease. Am J Respir Crit Care Med. 2013;187(7):715-720.

69. Makhlouf HA, Sadek SH, Nafady AA. Platelet function in diabetic and nondiabetic patients with chronic obstructive pulmonary disease: a case control study. Clin Respir J. 2016;10.1111/crj.12477.

70. Quanjer P, Weiner DJ, Pretto JJ, Brazzale DJ, Boros PW. Measurement of FEF $25 \%-75 \%$ and FEF $75 \%$ does not contribute to clinical decision making. Eur Respir J. 2014;43(4):1051-1058.

71. White P. Spirometry and peak expiratory flow in the primary care management of COPD. Prim Care Respir J. 2004;13(1):5-8.
International Journal of COPD

\section{Publish your work in this journal}

The International Journal of COPD is an international, peer-reviewed journal of therapeutics and pharmacology focusing on concise rapid reporting of clinical studies and reviews in COPD. Special focus is given to the pathophysiological processes underlying the disease, intervention programs, patient focused education, and self management protocols.

\section{Dovepress}

This journal is indexed on PubMed Central, MedLine and CAS. The manuscript management system is completely online and includes a very quick and fair peer-review system, which is all easy to use. Visit http://www.dovepress.com/testimonials.php to read real quotes from published authors. 